\title{
Animal Species Traded as Ethnomedicinal Resources in the Federal District, Central West Region of Brazil
}

\author{
Eraldo Medeiros Costa-Neto ${ }^{*}, 1$ and Paulo César Motta ${ }^{2}$ \\ ${ }^{1}$ Universidade Estadual de Feira de Santana, Departamento de Ciências Biológicas, Av. Transnordestina, s/n, 44036- \\ 900, Feira de Santana, Bahia, Brazil \\ ${ }^{2}$ Universidade de Brasília, Departamento de Zoologia, 70910-900, Brasília-DF, Brazil
}

\begin{abstract}
Animals have been used as treatment for various illnesses by many human cultures. This paper explores the phenomenon of zootherapy in the Federal District, Central West region of Brazil. Fieldwork was carried out from September to October 2006 by visiting one permanent free market in each of three cities within Brazilian Federal District. Data were obtained by open-ended interviews of six traders (four women and two men), who were questioned about zootherapeutic species, modes of use and administration of the folk remedies, as well as the diseases for which they are prescribed. A total of 30 animals belonging to nine taxonomic groups were recorded. Fats are the body parts most cited as sources of medicines $(\mathrm{n}=21 ; 57 \%)$, but other raw materials including leather, feather, gizzard, cartilage, liver (bile), milk, and spines are used to prepare both traditional medicines and charms. Zootherapy should be viewed from the multidimensional perspective of sustainable development. The exploration of animals for medicinal purposes should be a major subject in discussions on conservation biology, public health policies, sustainable management of natural resources, bioprospection and patents.
\end{abstract}

Keywords: Zootherapy, human-animal connection, sustainable use, commerce, Brazil.

\section{INTRODUCTION}

Natural products have been traditionally exploited as sources of bioactive metabolites for human benefit. Prior to the development of synthetic chemicals, plant and animal extracts were the only sources of organochemical and medical compounds. [1,2] Considering animal species, they are therapeutic arsenals that have been playing significant roles in the healing processes and magical-religious practices of peoples from all over the world, where folk remedies are elaborated from parts of the animal body, from products of its metabolism, such as corporal secretions and excrements, or from animal-made materials such as nests [3-8].

An early record for animal-based medicine can be found in Tobias' Book (Catholic Bible), in which Raphael the Angel would have prescribed the use of fish liver extract for ophthalmic problems [9]. The major difference between ancient medicine and modern medicine is that we are now able to chemically produce the hormones, vitamins and other substances which the ancient physicians (or their patients) had to extract from the organs of animals [10].

The medicinal use of animals and animal-derived products is known as zootherapy [11]. Although dismissed by many as nothing more than superstition, the value of traditional zootherapy is obvious to the pharmaceutical industry, which continues to test animal extracts as potential new drugs [12]. The strategic value of natural resources has

*Address correspondence to this author at the Universidade Estadual de Feira de Santana, Departamento de Ciências Biológicas, Av. Transnordestina, s/n, 44036-900, Feira de Santana, Bahia, Brazil; Tel/Fax: 5575 3224-8131; E-mail: eraldont@hotmail.com attracted the attention of the so-called bioprospectors, especially towards the tropics. In this regard, the investigation of tropical folk medicines has proven to be quite productive [13]. The annual global trade in animal-based medicinal products runs in the billions of dollars. For example, the commercialization of insect-based products comprises about USD \$ 100 million per year [14]. Angiotensin I, an antihypertensive derived from the Brazilian arrowhead viper Bothrops jararaca, brings the Squibb Company US $\$ 1.3$ billion a year in sales and contributes to the well-being and longevity of millions of people [15].

In Brazil as well as in other developing countries of the world, zootherapy is very deep-rooted in folk traditions. The zootherapeutic resources come from a great variety of animal species that can be found as profitable elements commercialized by herbalists and healers in free markets and in the streets all over the country. Unfortunately, many of the zootherapeutic resources include threatened species [16]. The large number of animal species used medicinally in Brazilian pharmacopoeia indicates the ethnobiological significance of this phenomenon, and necessitates public discussion about conservation biology, public health policies, bioprospection, patent laws, and sustainable management of natural resources [17].

The precise number of stalls that commercialize products of animal origin with magical-medicinal purposes in the Federal District is unknown, among other reasons due to the high number of stalls in informal commerce and temporary markets. Given the significance of the trade of zootherapeutic resources freely commercialized in the country, this study was intended to measure the extent and impact of zootherapy in Brazilian Federal District. It calls attention to 
the multidimensionality of zootherapy within a sustainable development agenda, since the exploration of animals for medicinal purposes should be one major subject in discussions on conservation biology, health public policies, sustainable management of natural resources, bioprospection, and patents. Farther studies are requested not only to confirm the presence of bioactive compounds in these traditional remedies, but also to lead to a more sustainable use of these resources.

\section{MATERIALS AND METHODS}

Fieldwork was carried out from September 30th to October 8th 2006 by visiting one permanent free market in each of three cities belonging to Brazilian Federal District, the political capital of Brazil. The selected cities were Planaltina, Guará and Sobradinho since they are near of the Federal Capital, Brasília, and because their free markets are the most important for regional economy. A brief description of them is as follows:

Planaltina is the oldest city of Federal District. It was built during the exploitation of gold and diamonds by the pioneers, as they arrived from the interior of Goiás State in the end of $18^{\text {th }}$ century. Industrialization came in the 1920's. Nowadays, there are 148.000 inhabitants [18].

The city of Guará was established in 1967 to lodge the workers of the Supply and Industry Sector, invasions, public servers, and provisional cores. More than 115.000 people live in this city [18].

The city of Sobradinho was founded in May, 1960, along the old road between the city of Planaltina and the federal capital, in order to lodge the immigrating families from the state of Goiás and Northeastern of Brazil. The number of inhabitants is approximately 130.000 [18].

Data were obtained through open-ended interviews of volunteering merchants of medicinal products. Four women and two men, ranging in age from 32 to 59 years old, were interviewed. Photos were taken with their permission. Most of the potential respondents who traded on animal-derived medicinal products did not want to be interviewed because they feared for their personal and labor security, even though we have told them that we did not belong to any federal agency of environmental protection, and guaranteed their anonymity in the study. That is why the low number of interviewees. In addition the number of stalls varied from one market to another because many of them were closed during the visiting days. Those traders who have consented to be interviewed were questioned about zootherapeutic species, modes of use and administration of the folk remedies, as well as the diseases for which they are prescribed.

Sample products were purchased and deposited in the scientific collection of the Ethnobiology and Ethnoecology Laboratory of the Feira de Santana State University. Species were identified by comparing their folk names to the literature and because most of them are very common animals.

The medicinal use-value of each animal has been estimated according to the following equation:

$$
\frac{\mathrm{UV}=\mathrm{SRM} \times \mathrm{C}}{\mathrm{N}}
$$

where UV represents the medicinal use-value; RM refers to the total number of different tissues or extracts used; $\mathrm{C}$ refers to the number of times which a particular animal has been cited; and $\mathrm{N}$ refers to the total number of informants questioned about zootherapy. This quantitative method was developed to calculate the relative usefulness of different plant species within a given community [19].

\section{RESULTS AND DISCUSSION}

This is the first time that such a systematic survey was done in this geopolitical region. A total of 30 animals belonging to nine taxonomic groups were recorded. These are Mammalia (nine representatives), Reptilia (7), Aves (4), Insecta (3), Osteichthyes (2), Chondrichthyes (2), Asteroidea (1), Amphibia (1), and Oligochaeta (1) (Table 1). Fats and oils were the body parts most often cited as sources of medicines $(n=21 ; 57 \%)$. Other tissues included dried skin, feather, gizzard, cartilage, liver (bile), milk, and spines. These ingredients were used to prepare both medicines and charms. For example, a live velvet ant (Hymenoptera, Mutillidae) would be placed inside a piece of cloth and tied around a child's neck to treat bronchitis.

It must be said that considering folk medicine system the term "sickness" is used here in a broad sense to refer both to the illnesses which have a personalistic origin (caused by a human or supernatural agent) and those having a naturalist origin (provoked by the intervention of natural causes or forces), ranging from painful conditions to mental disorders [20].

Rodrigues [21] also found frequent use of animal fat $(69 \%)$ in a study carried out at the Jaú National Park, Brazilian Amazon. He stressed that the fat was generally extracted from the ventral part of the animal, then melted down and stored in glass bottles until use. In a traditional fishermen community from Bahia State, Costa-Neto and Marques [9] recorded that the fat of 17 different animals were the most common medicines.

Adulteration of zootherapeutics has been described elsewhere [12, 22]. And it may exist in Brazilian Federal District as well. One trader from Guará market said she trusted the content of the ram and the chicken fat brought to her by suppliers, but not the fats provided by other suppliers, who might mix the animal oils with cooking oil. One trade reported that the shelf-life of these oils is about a year.

\section{FOLK PRESCRIPTIONS OF THE ZOOTHERA- PEUTICS}

We could observe that vulture (Cathartidae), alligator (Crocodilidae), rattlesnake (Crotalus durissus), rhea (Rhea americana) and ram (Ovis aries) were the most significant zootherapeuticals for which their medicinal use-values (UV) were $1.33,1.0,0.83,0.66$, and 0.66 , respectively (Table $\mathbf{1}$ ).

Rattlesnake, ram, chicken and capybara were the most cited animals by the interviewed traders (see Table 1), but the folk remedies based on these animals may not be the most tradable.

Animal-based folk remedies (Fig. 1) are administered as plasters, teas, smokes, or foods. Teas, for example, are made 
Table 1. Zootherapeutic Resources Traded in Three Free Markets of the Federal District, Brazil. NC= Number of Citation; UV $=$ Medicinal Use-Value

\begin{tabular}{|c|c|c|c|c|c|}
\hline \multicolumn{2}{|c|}{ Cited animals } & \multirow[b]{2}{*}{ Raw material } & \multirow[b]{2}{*}{ Therapeutic use } & \multirow[b]{2}{*}{ NC } & \multirow[b]{2}{*}{$\mathbf{U V}$} \\
\hline $\begin{array}{l}\text { Common name/ } \\
\text { English name }\end{array}$ & Probable scientific name & & & & \\
\hline $\begin{array}{l}\text { Estrela-do-mar } \\
\text { Starfish }\end{array}$ & Asteroidea & Whole & Asthma & 1 & 0.16 \\
\hline $\begin{array}{l}\text { Minhoca-preta } \\
\text { Black earthworm }\end{array}$ & Oligochaeta & Whole & Schistosomosis, lumps & 1 & 0.16 \\
\hline $\begin{array}{l}\text { Cupim-preto } \\
\text { Black termite }\end{array}$ & Isoptera & Whole & Tuberculosis & 1 & 0.16 \\
\hline $\begin{array}{c}\text { Oncinha } \\
\text { Velvet ant }\end{array}$ & Mutilidae & Whole & Bronchitis & 1 & 0.16 \\
\hline $\begin{array}{l}\text { Besouro-do-amendoim } \\
\text { Peanut beetle }\end{array}$ & Palembus dermestoides & Whole & Aphrodisiac, energetic reposition & 2 & 0.33 \\
\hline \multirow{2}{*}{$\begin{array}{c}\text { Jia } \\
\text { Frog }\end{array}$} & \multirow{2}{*}{ Anura } & Fat & Rheumatism, depurative & 1 & 0.33 \\
\hline & & Meat & Parkinson's disease & & \\
\hline $\begin{array}{l}\text { Arraia } \\
\text { Ray }\end{array}$ & Condrichthyies & Oil & Rheumatism & 1 & 0.16 \\
\hline $\begin{array}{l}\text { Tubarão } \\
\text { Shark }\end{array}$ & Carcharhinidae & Cartilage & $\ldots$ & 1 & 0.16 \\
\hline $\begin{array}{l}\text { Cavalo-marinho } \\
\text { Seahorse }\end{array}$ & Hippocampus sp. & Whole & Asthma & 1 & 0.16 \\
\hline $\begin{array}{l}\text { Peixe-elétrico } \\
\text { Electric fish }\end{array}$ & Electrophorus electricus & Fat & Rheumatism & 1 & 0.16 \\
\hline $\begin{array}{c}\text { Sucuri } \\
\text { Anaconda }\end{array}$ & Eunectes sp. & Oil & Rheumatism & 2 & 0.33 \\
\hline $\begin{array}{c}\text { Cascavel } \\
\text { Rattlesnake }\end{array}$ & Crotalus durissus & Oil & $\begin{array}{l}\text { Bronchitis, arthritis, joint problems, cancer, } \\
\text { back-aches }\end{array}$ & 5 & 0,83 \\
\hline $\begin{array}{c}\text { Jibóia } \\
\text { Boa }\end{array}$ & Boa constrictor & Oil & Rheumatism & 1 & 0.16 \\
\hline $\begin{array}{c}\text { Tiú } \\
\text { Tegu lizard }\end{array}$ & Tupinambis sp. & Oil & Earache, deafness & 2 & 0.33 \\
\hline $\begin{array}{l}\text { Tartaruga } \\
\text { Turtle }\end{array}$ & Chelidae & Oil & Rheumatism & 1 & 0.16 \\
\hline $\begin{array}{c}\text { Jacaré } \\
\text { Alligator }\end{array}$ & Crocodilidae & Dried skin, oil & Rheumatism & 3 & 1,0 \\
\hline $\begin{array}{c}\text { Galinha-d'angola } \\
\text { Helmeted guinea fowl }\end{array}$ & Numida meleagris & Fat & Influenza, bronchitis & 1 & 0.16 \\
\hline $\begin{array}{l}\text { Galinha-caipira } \\
\text { Chicken }\end{array}$ & Gallus gallus & Oil & Influenza, asthma, bronchitis, expectorant & 3 & 0.5 \\
\hline $\begin{array}{c}\text { Urubu } \\
\text { Vulture }\end{array}$ & Cathartidae & $\begin{array}{c}\text { Feather liver (bile), oil, } \\
\text { gizzard }\end{array}$ & Alcoholism & 2 & 1.33 \\
\hline $\begin{array}{l}\text { Pato } \\
\text { Duck }\end{array}$ & Anas sp. & Fat & Gripe, bronchitis & 1 & 0.16 \\
\hline \multirow{2}{*}{$\begin{array}{l}\text { Ema } \\
\text { Rhea }\end{array}$} & \multirow{2}{*}{ Rhea americana } & Oil & Bronchitis, asthma & \multirow{2}{*}{2} & \multirow{2}{*}{0.66} \\
\hline & & Gizzard & Rickets, anemia & & \\
\hline $\begin{array}{c}\text { Boto } \\
\text { Dolphin }\end{array}$ & Sotalia sp. & Oil & Rheumatism & 1 & 0.16 \\
\hline $\begin{array}{l}\text { Paca } \\
\text { Paca }\end{array}$ & Cuniculus paca & Oil & Discharge & 1 & 0.16 \\
\hline $\begin{array}{l}\text { Vaca } \\
\text { Cow }\end{array}$ & Bos taurus & $\begin{array}{l}\text { Milk (cream) } \\
\text { Milk (butter) }\end{array}$ & Burns, expectorant & 1 & 0.33 \\
\hline $\begin{array}{l}\text { Carneiro } \\
\text { Ram }\end{array}$ & Ovis aries & Oil & Aches in general, esp. arthritis, feet crackers & 4 & 0.66 \\
\hline $\begin{array}{l}\text { Luís-cacheiro } \\
\text { Prehensile-tailed } \\
\text { porcupine }\end{array}$ & Coendou sp. & Spine & & 1 & 0.16 \\
\hline
\end{tabular}


(Table 1) Contd......

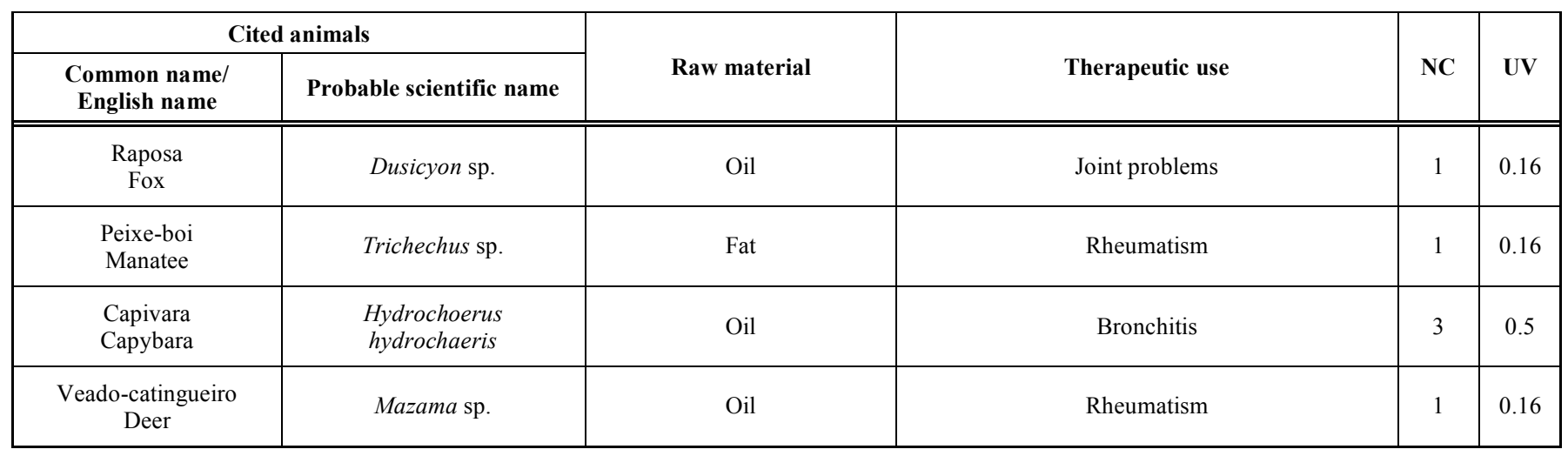

by grinding the toasted or scraped parts of the body of the animals or the whole toasted animal into a powder. Such is the case with echinoderms (starfish) and fish (seahorse). Fats from rattlesnake and the anaconda are massaged in order to heal rheumatic and muscle aches. Rattlesnake fat is recommended also for the treatment of bronchitis and cancer. The fat of a tegu lizard (Tupinambis spp.) has long been recommended by ancient people for earaches. Some drops of it are placed on a piece of cotton and then inserted into the ear. This fat is widely used as folk medicine throughout Brazil and other areas of Latin America, as well. The seringa collectors who live in the Upper Juruá Extractive Reserve (Acre, Brazil) recommend its use to treat earaches, rheumatism and snakebites [23].

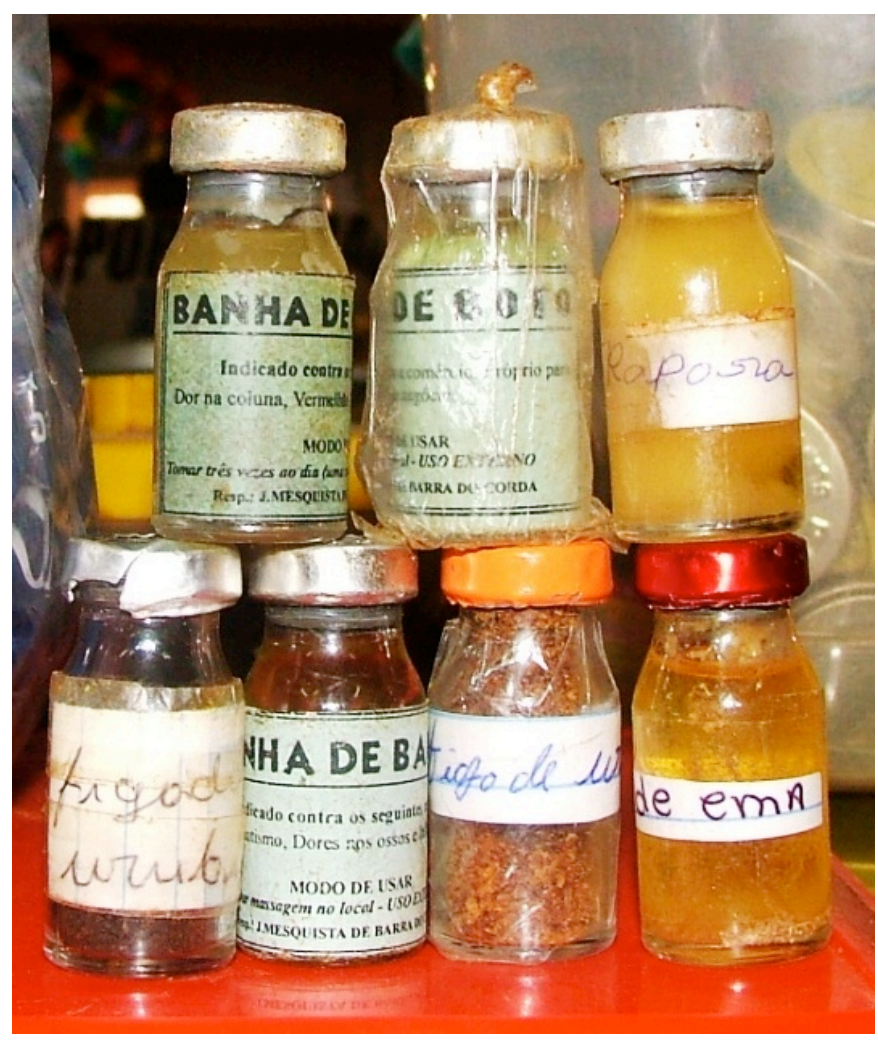

Fig. (1). Examples of zootherapeuticals traded in markets of Brazilian Federal District.
The rhea's gizzard membrane is recommended for asthma, bronchitis, and anemia. It should be sun-dried and then toasted. After that, the powdered material is drunk as a tea or mixed in someone's meal; honey may be added. The fats of chicken, helmeted guinea fowl and duck are sold as an expectorant in cases of influenza and bronchitis. Chicken fat has been reported to treat earaches and asthma [23].

Other animal-based medicinal products, such as the bile of a vulture, are obtained only by special order. Vultures are examples of multiple use zootherapeutic resource since different body parts are traditionally used (feathers, liver, gizzard, and fat). This is demonstrated by the medicinal usevalue of 1.33, the greatest of all among the surveyed zootherapeutic animal species. The powdered bile is used for alcoholism: it should be put inside the drink of an addicted person in order to make him loose his addiction. One of the interviewee's sisters had successfully used this treatment for her husband. Traders often used as well as sold the animalbased folk medicines. The owner of a stall at the Sobradinho market used the milk cream to treat her burns. Another interviewee used the fat of a ram for joint pain.

\section{THE ECONOMIC VALUE OF ZOOTHERAPEUTICS}

The possession of a stall was inherited, handed down from parents to their children. The father of a trader from Sobradinho market already owned an herb stall. A trader from Guará market said her father was an herbalist and her mother was "fanatic for these things". A trader from Planaltina market said he learned about zootherapeutic products from his parents.

The little glass contenders containing the fats of different animals cost between R\$2.00 to 5.00 (US\$ 1.00 equals to R\$ 1.80 on 25th of August 2008). The jug with ram's fat costs R\$ 3.00. The price of a caiman's leather depends on the size of the sold part. A small piece of caiman's leather cost one real ( $\mathrm{R} \$ 1.00)$. A small can with shark cartilage sold at $\mathrm{R} \$ 1.50$, and the fat of a rattlesnake costs about $\mathrm{R} \$ 2.00$. According to two traders, chicken fat is most often sold during winter because it is recommended for asthma and as an expectorant.

A trader who works at the Planaltina market reported that most of his suppliers came from Northeastern Brazil. Indeed, 
this region of the country has been extensively surveyed for zootherapeutic practices [24]. Another salesman from this same market has stated that some of the products are brought to him by countryside individuals. People who search for these zootherapeuticals generally approach the sellers already knowing which products they want to buy and for what purpose. Most of the users are elderly; others are referred by friends or family. As one salesman said, "People look for [the faunal medicines] every moment".

One of the traders from Guará market is aware that selling animal-made products is against law and that is why she has a little amount of these products to sell. She has stressed that sellers can not medicinally recommend any of the products because the Sanitary Vigilance National Agency prohibits it. Farther studies are requested not only to confirm the presence of bioactive compounds in these traditional remedies, but also to lead to a more sustainable use of these resources.

\section{RISKS TO HUMAN HEALTH}

Although presenting bioactive compounds potentially useful for pharmacology, faunistic resources extracted from wild and traded as ethnomedicinal products can also cause serious adverse reactions due to very bad conditions involved in the preparation and conservation of the zootherapeutics. It is primordial that animal-based medicines made from their body parts (feather, bone, dried skin, internal organs etc.), with materials elaborated by them (nests), or products of their metabolism (venom, feces, urine) be submitted to an analysis of risks and benefits.

Several infectious diseases can be transmitted from animals to human beings (zoonoses). Alves and Rosa [25, 26] call attention for the possibility of transmitting infections or diseases by the animal preparations to the users of zootherapeutics, thus this factor must be seriously taken into account. For example, several organs and tissues, including bones and bile, can be a source of infection by salmonella, causing chronic diarrhea and endotoxic chock. Other serious and widespread zoonoses such as rabies can be transmitted if tissues of an unknown animal are handled and used as traditional medicines. Besides, there is also the possibility of having toxic or allergic reactions to animal products.

The zootherapeutics are generally traded without considering their sanitary conditions. This fact can cause the aggravation of the symptoms which that same 'medicine' should heal, or even provoke damages in other organs and systems of the user (patient), maybe leading him/her to death. It is important, then, to carry out microbiological surveys in order to detect the microbiological pathogenicity level of the medicinal use of products and/or traditional medicines based on animal's raw materials. Alves and Rosa [25] argue that the implementation of sanitary measures to the trade of animals or their parts for medicinal purposes implies significant challenges, such as ensuring suitable participation of all stakeholders involved, combating illegal, unreported and unregulated trade, and monitoring of the activity.

\section{CONSERVATION}

Traditional knowledge on medicinal compounds from natural resources (animals included!) is still one of the most important means for discovery of unknown biotic drug sources $[2,27]$. The international interest both for the control and exploration of the biological diversity has expressively increased in the last years due to the economic potentiality that natural resources mean [28]. And this has led some natural resources to be vulnerable to extinction due to overharvesting or excessive habitat loss. For example, the overexploitation of Polyhachis vicina Roger (weaver ant) in Chine is threatening the species [14].

The economical value of zootherapy, as expressed by those who trade animal-based medicines, should be taken into account whenever one makes political and environmental measures against this trade [6, 17, 25, 26, 29]. Instead of sending the practitioners of zootherapy to prisons, or creating policies which force them to abandon such a practice, decision-makers should view this human/nature connection within its cultural dimension. The value of animal-based medicines is very significant; they are usually the main available resources for the majority of the human population who has limited access to official medicines and proper medical care. Since people have been using animals for a long time, suppression of their use will not save them from extinction [17]. Considering the sea turtles, Carr [30] says "people have been eating turtles pretty steadily for as long as they have had the wits to get them out of their shells". In addition, millions of hatchlings are caught annually for the pet market.

A growing body of literature shows that the cultural aspects of a given human/nature inter-relation should be taken into account in every debate related to sustainable development [31-33]. This cultural perspective includes the way people perceive, use, allocate, transfer, and manage their natural resources [13]. As Alcorn [34] states, "Conservation is a social and political process". In this way, discussing the relationship between food availabilities that are provided by the environment, their trophic use, the physiological consequences resulted form their eating, as well as the social-economical structures that support them within the multidimensionality of the sustainable development is one of the key elements to achieve sustainability [11, 17].

It is critical that biodiversity be maintained to provide future structural diversity and provide leads and drugs for new targets for pharmaceutical events that will emerge in the coming years. The diminishing number of animal species, especially from Neotropical areas, through hunting, depauperation of their ecosystems, and their varied uses has been enormous that most of them are becoming extinct even before they have been studied by science [17]. Hence, studies aimed towards traditional knowledge on animal use and its significance to men should be undertaken in order to lead to better ways of exploiting the natural resources. Those species involved in traditional remedies should be among the highest priorities for conservation [35]. 
A pilot study carried out with 50 traders of the Ijebu and Ibadan ethnical groups from the Southeast Nigeria has recorded the use of 40 animal species as sources of traditional medicines [36]. Out of these, 16 are listed as threatened species in the country. In this way, it is necessary to educate the traders about the effect of their commerce on the threatened species, the resulting impact on biodiversity and on the nation as a whole. Since people constitute an essential component of the landscape and their activities are fundamental for its long-term compatible use, biological conservation policy should be built on a social-cultural basis. Thus, discussing zootherapy within the multidimensionality of the sustainable development turns out to be as one of the key elements in order to achieving the sustainability of the medicinal faunistic resources. Additionally, the exploration of animals for medicinal purposes should be one major subject in discussions on conservation biology, health public policies, sustainable management of natural resources, bioprospection, and patents.

All in all, these results are meant to be just a glimpse of the actual phenomenon that occurs throughout the Federal District and other regions of the country. Farther research in the Federal District's free markets should be done in order to increase the number of respondents, and consequently the number of animal species that are traded for medicinal and magical purposes.

The persistent use of animal-based medicines means that substances of therapeutic value not yet known by science may be really present. Both Western and traditional medical systems have a lot to offer medicinally, economically, and culturally. In this way, public health care practitioners should try to integrate them instead of attempting to replace one by another.

\section{ACKNOWLEDGEMENTS}

The authors would like to thank all merchants from the visited markets who allow to reproduce their traditional knowledge. Without their collaboration this work would not have been possible.

\section{REFERENCES}

[1] McGirk T. Gene piracy. Time 1998; Nov: 20-5.

[2] Oldfield ML. The value of conserving genetic resources. Washington, D.C: National Park Service 1989.

[3] Antonio TMF. Insects as remedies in Zaire. The Food Insects Newsl 1994; 7: 4-5.

[4] Araújo AM. Medicina rústica. São Paulo: Companhia Editora Nacional 1977.

[5] Conconi JE, Pino JMM. The utilization of insects in the empirical medicine of ancient Mexicans. J Ethnobiol 1988; 8: 195-202.

[6] Costa-Neto EM. Healing with animals in Feira de Santana city, Bahia, Brazil. J Ethnopharm 1999; 65: 225-30.

[7] Gudger EW. Stitching wounds with the mandibles of ants and beetles. J Am Med Assoc 1925; 84: 1862-4.

[8] van Huis A. The traditional use of arthropods in Subsaharan Africa. Proc Experim Appl Ent 1996; 7: 3-20.

[9] Costa-Neto EM, Marques JGW. Faunistic resources used as medicines by artisanal fishermen from Siribinha Beach, state of Bahia, Brazil. J Ethnobiol 2000; 20: 93-109.
[10] Sousa MASM. A arte médica antiga nos De Medicine de Celso. Agora. Est Class em Debate 2005; 7: 81-104.

[11] Costa-Neto EM. Barata é um santo remédio: introdução à zooterapia popular no Estado da Bahia. Feira de Santana: UEFS 1999.

[12] Marques JGW. Da cartilagem de tubarão à batata de teiú (passando pela carne de urubu): remédios novos ou velhas fantasias? Paper presented at the Encontro de Zoologia do Nordeste, Feira de Santana 1999.

[13] Johannes RE. Integrating traditional ecological knowledge and management with environmental impact assessment. In: Inglis JT, Ed. Traditional ecological knowledge: concepts and cases. Ottawa: IDRC 1993; 33-9.

[14] Thémis JL. Des insects à croquer: guide de découvertes. Québec: Les Éditions de l'Homme 1997.

[15] Kunin WE, Lawton JH. Does biodiversity matter? Evaluating the case for conserving species. In: Gaston KJ, Ed. Biodiversity: a biology of numbers and difference. Oxford: Blackwell Science 1996; 283-308.

[16] Sá V de. O zoológico médico brasileiro. Folha de São Paulo 1995; $7^{\text {th }}$ May: 17.

[17] Costa-Neto EM. Animal-based medicines: biological prospection and the sustainable use of zootherapeutic resources. An Acad Bras Cienc 2005; 77: 33-43.

[18] Governo do Distrito Federal. Regiões administrativas: dados demográficos. Available at http://www.df.gov.br/.[Accessed Sept. 15, 2008].

[19] Cotton CM. Ethnobotany: principle and applications. New York, NY: John Wiley and Sons 1996.

[20] Foster G. Introduction a l'ethnomédicine. In: Bannerman RH, Burton J, Wen-Chien C, Eds. Médicine traditionalle et couverture des soins de santé, Geneva: OMS 1983; 17-24.

[21] Rodrigues E. Plants and animals utilized as medicines in the Jaú National Park (JNP), Brazilian Amazon. Phytother Res 2006; 20: 378-91.

[22] Marques JGW. Fauna medicinal: recurso do ambiente ou ameaça à biodiversidade? Mutum 1997; 1: 4.

[23] Begossi A, Silvano RAM, Amaral BD, Oyakawa OT. Uses of fish and game by inhabitants of an extractive reserve (Upper Juruá, Acre, Brazil). Environ Dev Sust 1999; 1: 73-93.

[24] Alves RNN, Rosa IL. Zootherapeutic practices among fishing communities in North and Northeast Brazil: a comparison. J Ethnopharm 2007; 111: 82-103.

[25] Alves RNN, Rosa IL. Why study the use of animal products in traditional medicines? Available at http://www.ethnobiomed.com/ content/3/1/14.[Accessed Apr. 4, 2006].

[26] Alves RNN, Rosa IL. Biodiversity, traditional medicine and public health: where do they meet? Available at http://www.ethnobiomed. com/content/3/1/14>. [Accessed Apr. 4, 2007].

[27] Müller WEG, Batel R, SchRönder HC, Müller IM. Traditional and modern biomedical prospecting: Part I - The history sustainable exploitation of biodiversity (sponges and invertebrates) in the Adriatic Sea in Rovinj (Croatia). eCam 2004; 1: 71-82.

[28] Calixto JB. Biopirataria. Ciência Hoje 2000; 28: 36-43.

[29] Andrade JN, Costa-Neto EM. O comércio de produtos zooterápicos na cidade de Feira de Santana, Bahia, Brasil. Sitientibus ser Ci Biol 2006; 6: 37-43.

[30] Carr A. Handbook of turtles. The turtles of the United States, Canada, and Baja California. New York: Cornell University Press 1996.

[31] Agrawal A. Indigenous and scientific knowledge: some critical comments. IKDM 1995; 3: 1-10.

[32] Morin-Labatut G, Akhtar S. Traditional environmental knowledge: a resource to manage and share. Development 1992; 4: 24-30.

[33] Zwhalen R. Traditional methods: a guarantee for sustainability? IKDM 1996; 4: 1-7.

[34] Alcorn JB. Indigenous peoples and conservation. In: Ehrenfeld D, Ed. Readings from conservation biology. Oxford: Blackwell Science 1995; 20-22. 
[35] Lovejoy TE. Biodiversity, what is it? In: Reaka-Kudla ML, Wilson DE, Wilson EO, Eds. Biodiversity II: understanding and protecting our biological resources. Washington, D.C: Joseph Henry Press 1997; 7-14.
[36] Dedeke GA, Soewu DA, Lawal AO, Ola M. Pilot survey of ethnozoological utilization of vertebrates in Southwestern Nigeria. Indilinga. African J Ind Knowl Syst 2006; 5: 87-96.

Received: January 05,2010

(C) Costa-Neto and Motta; Licensee Bentham Open.

This is an open access article licensed under the terms of the Creative Commons Attribution Non-Commercial License (http://creativecommons.org/licenses/by$\mathrm{nc} / 3.0 /$ ), which permits unrestricted, non-commercial use, distribution and reproduction in any medium, provided the work is properly cited. 